\title{
Simultaneous Monitoring and Control of Automation Systems with SCADA Based PLC
}

\section{Otomasyon Sistemlerinin SCADA Tabanlı PLC ile Aynı Anda Izzlenmesi ve Kontrolü}

\begin{abstract}
Məryəm Məmmədli ${ }^{1}$, Rana Ortaç Kabaoğlu ${ }^{2 *}$
Geliş / Received: 18/03/2021

Revize / Revised: 07/04/2021

Kabul / Accepted: 08/04/2021

ABSTRACT

As technology develops all over the word, it is desired to be more efficient and less costly, and automatic control systems are demanded accordingly. The most important duties of the elements that constitute the automatic control system are quality of the established system and being cheap and functional. SCADA and PLC control systems, which are among the significant control systems, are utilized to implement these conditions placed against the elements. SCADA and PLC systems are automatic control systems that are very popular today. Both of them are used in almost every field of industry. This study has been implemented in the Academy automation R\&D laboratory and applications have been developed with PLC and SCADA, which are indispensable for automation systems. All systems are connected to SCADA using 3 types of PLC, S7-300, S7-1200, S7-1500 and also MODBUS devices. These four systems transferred to SCADA are monitored on a screen. At the same time, the feature of being able to intervene in the system in case of malfunction, which is one of the important advantages of the SCADA system, has also been used.
\end{abstract}

Keywords- Control Systems, PLC, Modbus Device, SCADA System

öz

Teknoloji geliştikçe, dünyanın her yerinde daha verimli ve daha az maliyetli olması istenmekte ve buna uygun otomatik kontrol sistemleri talep edilmektedir. Otomatik kontrol sistemini oluşturan unsurların en önemli görevi, kurulan sistemin kaliteli, ucuz ve işlevsel olmasıdır. Önemli kontrol sistemleri arasında yer alan SCADA ve PLC kontrol sistemleri, bu isteklere karşı, bu koşulları gerçekleştirmek için kullanılmaktadır. SCADA ve PLC sistemleri, günümüzde oldukça popüler olan otomatik kontrol sistemleridir. Her ikisi de endüstrinin hemen hemen her alanında kullanılmaktadır. Bu çalışma Akademi otomasyon Ar-Ge laboratuvarında gerçekleştirilmiş ve otomasyon sistemlerinin vazgeçilmezi olan PLC ve SCADA ile uygulamalar geliştirilmiştir. Tüm sistemler 3 tip PLC, S7-300, S7-1200, S7-1500 ve ayrıca MODBUS cihazları kullanılarak SCADA'ya bağlanmış. SCADA'ya aktarılan bu dört sistem bir ekran üzerinden izlenmiştir. Aynı zamanda SCADA sisteminin önemli avantajlarından biri olan, arıza durumunda sisteme müdahale edilebilmesi özelliği de kullanılmıştır.

Anahtar Kelimeler- Kontrol Sistemleri, PLC, Modbus Cihazı, SCADA Sistemi

1İletişim: memmedlimeryem96@mail.ru (https://orcid.org/0000-0001-5578-4517)
Department of Electrical-Electronics Engineering, Istanbul University-Cerrahpasa, Avclar, Istanbul,Turkey
2*Sorumlu yazar iletișim: rana@istanbul.edu.tr (https://orcid.org/0000-0003-0861-0711)
Department of Electrical-Electronics Engineering, Istanbul University-Cerrahpasa, Avclar, Istanbul, Turkey 


\section{INTRODUCTION}

Today, it is observed that automation technology is in an excessive development. Manufacturers would like that the personnel control these systems to be both high-quality, cheap, and fully meet the desired duty [1]. The systems that can control such systems in the most economical, efficient, and effective way are the systems created by controlling SCADA and PLC [2]. Automation systems have many advantages over relay and computerized (PC) systems [3]. For these reasons, they are widely used.

Programmable Logic Controllers (PLC) are control and command elements that contain PIC processors as well as EEPROM programmers and have a significant role in today's technology [4]. The reason why the devices are called Programmable Logic Controller is that they are designed as an alternative to logic-based relay systems. One of the important features of PLCs is that the memory functions, such as counter and time elements are ready designed by the manufacturers. In solving control problems, this feature of PLC is easily utilized with simple programming [5]. PLC is a device that transmits the information received from elements, such as keys, buttons, and sensors for the program written by the user into logic values and transmits them to the output section [6]. Programmable Logic Controllers, also known as microprocessors, have started to appear in our history in 1968 [7]. These PLCs have been used in the automobile industry for mass production [8]. PLCs released in the past tense, differ from PLCs produced today in both terms of size and control of the systems [9]. Today, PLCs can easily adapt to the desired system [10]. With developing the automation technology, PLCs have also been improved [11].

Supervised Control and Data Acquisition system (SCADA) has started to show itself in the 1960s. In the past, the SCADA system consisted of elements, such as signal lights, measuring instruments, and tape recorders [12]. Over time, computers and automation systems improved and the SCADA system did not remain indifferent to this development [13].

Today, SCADA system is applied in almost every area where automation is used. There are many reasons for this frequent use. For example, some situations that are dangerous for human life have disappeared in the networks where SCADA system is used [14]. In addition, it is possible to easily get information about the process monitored by the SCADA system and to intervene in the system remotely by finding faulty components in case of malfunction [15].

Since the SCADA system operates according to the user's demands, the system to be controlled is more reliable, and the number of users is less. One of the advantageous features of this system is the ability to get reports. The past and present values of the system which are controlled by using the reporting feature can be taken as a report.

One of the significant features of SCADA is to give an alarm (warning). When the set values change, the user is informed by the alarm.

\section{APPLICATION MATERIALS}

In this study, integration of SCADA with PLC and IOT technology is realized in Automation Academy $R \& D$ laboratory environment. This work is carried out with three different PLCs and Arduino. TIA Portal program is used for programming PLCs and SCADA application, and Arduino IDE compiler is used for Arduino programming.

The used PLC types are S7-300, S7-1200 and S7-1500. In the application to be made with the S7-300, analog transactions are read on the SCADA system. The reading process is performed with the temperature sensor that is attached to the transmitter connected to the analog module of the PLC. According to the temperature values set by the user, the output speed of the fan connected to the asynchronous motor changes gradually.

In the application to be made with the S7-1200, the step and servo motors of the spring bending machine work synchronously with each other. By making the recipe application, the length of the spring to be bent is entered into the system via the user's SCADA system and step motor and servo motor control are provided.

In the application to be made with the S7-1500, the products passing over the conveyor are read by two different sensors, and depending on the algorithm on the PLC, the reading values are decided whether the product is defective or not. Defective products are separated by pushing them over the conveyor with a pneumatic valve. 
In the application to be made with Arduino, the humidity of the greenhouse to which the system is connected is checked. The values read from the humidity sensor are sent to the SCADA system via serial communication over the master device. The data from all these PLCs and Arduino are read and displayed on the computer and the SCADA project is completed with the control application.

\section{DEVELOPED APPLICATIONS}

\section{A. Temperature Dependent Speed Control with S7-300 PLC}

In the application to be made with the S7-300, analog transactions are read on the SCADA system. The reading process is performed with the temperature sensor that is attached to the transmitter connected to the analog module of the PLC. The connection diagram of the system to be made with S7-300 PLC is shown in Figure 1.

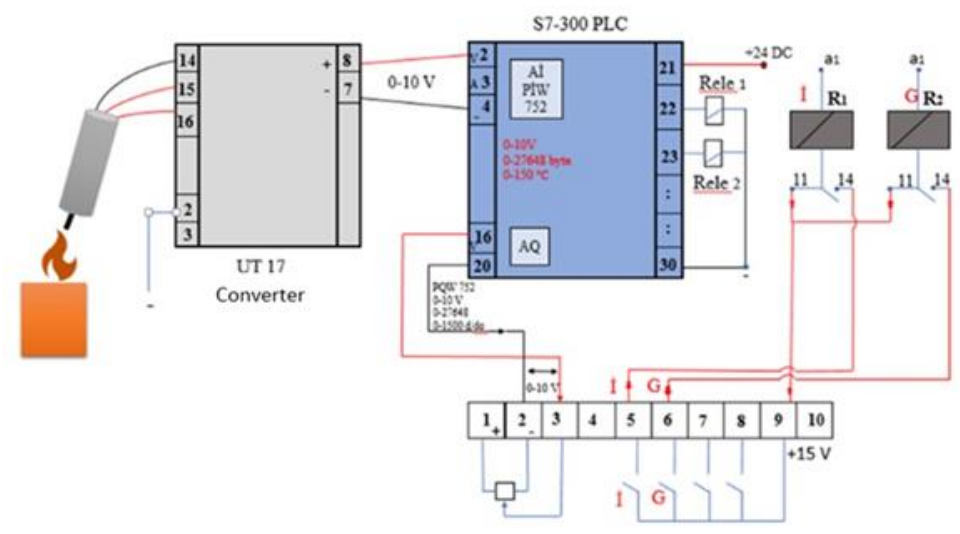

Figure 1. S7-300 PLC and Escon driver connection diagram

As can be seen from the connection diagram in Figure 1, the devices used in speed control application are shown in Table 1;

Table 1. List of used devices

\begin{tabular}{lcl}
\hline Device name & Number of & Device features \\
\hline PIC & 1 & S7-300 CPU 313C \\
Temperature drive & 1 & PT100 \\
Converter & 1 & UT17 \\
Driver & 1 & Eskon drive \\
3 Asynchronous motor & 1 & - \\
\hline
\end{tabular}




\begin{tabular}{|c|c|c|}
\hline & $\begin{array}{l}\text { BŞEÜ Fen Bilimleri Dergisi } \\
8(1), 336-344,2020\end{array}$ & $\begin{array}{r}\text { BSEU Journal of Science } \\
\text { https://doi.org/10.35193/bseufbd.899424 }\end{array}$ \\
\hline $\begin{array}{l}\text { BilLECIKSEYHEDEBALI } \\
\text { UNIVERSITESI }\end{array}$ & & 2458-7575 (https://dergipark.org.tr/tr/pub/bseufbd) \\
\hline
\end{tabular}

Figure 2 shows the system set up in a laboratory environment:

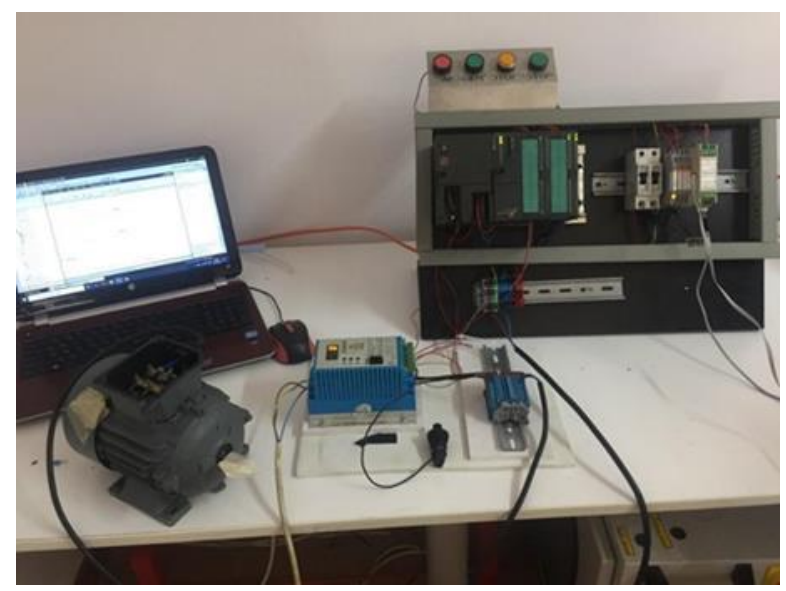

Figure 2. S7-300 PLC system connected in a laboratory environment

After the connection is made, the motor can be operated in forward and backward direction by adjusting the outputs of Q124.0 and Q124.1 with the M0.2 and M0.3 bits and using TIA Portal software. In order not to damage the engine in forward and backward direction, its operation is prevented at the same time by electrical locking method.

Speed control is implemented by creating a ladder diagram. Ladder diagrams of S7-300 PLC system installed in TIA Portal environment are written using 6 networks.

\section{B. Synchronous Operation of Step and Servo Motors of Spring Bending Machine with S7-1200 PLC}

In the application to be made with S7-1200, step and servo motors of the spring bending machine are synchronized with each other. By making a recipe application, the length of the spring to be bent is entered into the system via the user's SCADA system, and step motor and servo motor control is provided.

The connection diagram of the system to be made with S7-1200 PLC is shown in Figure 3;

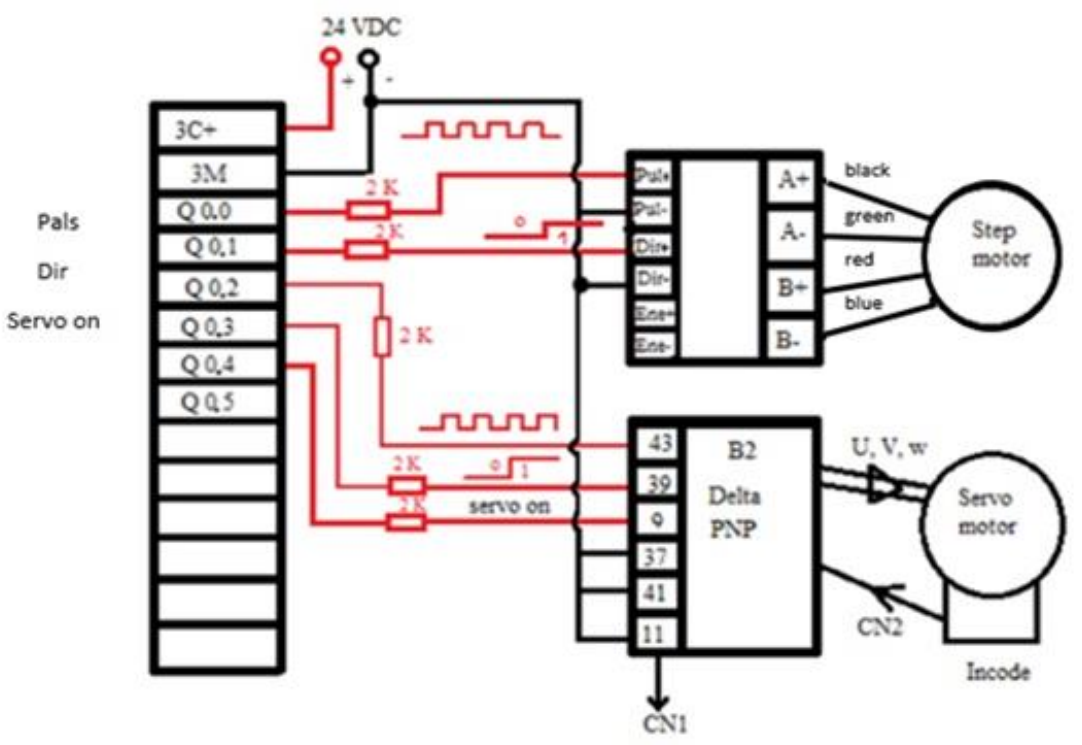

Figure 3. Connection diagram of S7-1200 PLC and step and servo motor drivers 
BŞEÜ Fen Bilimleri Dergisi

8(1), 336-344, 2020
BSEU Journal of Science

https://doi.org/10.35193/bseufbd.899424

in Table 2;

As can be seen from connection diagram in Figure 3, the devices used in synchronous operation are shown

Table 2. List of devices which are used

\begin{tabular}{lcc}
\hline Device name & Number of & Device features \\
\hline PLC & 1 & S7-1200 CPU 1212C DC/DC/DC \\
Step motor & 1 & Leadshine \\
Step motor driver & 1 & Leadshine M542 \\
Servo motor & 1 & Delta, ECMA-C20807GS \\
Servo motor driver & 1 & Delta, ASD-B2-0721-B \\
\hline
\end{tabular}

In the Automation Academy R\&D laboratory environment, the shape of the system with a connection diagram is shown.

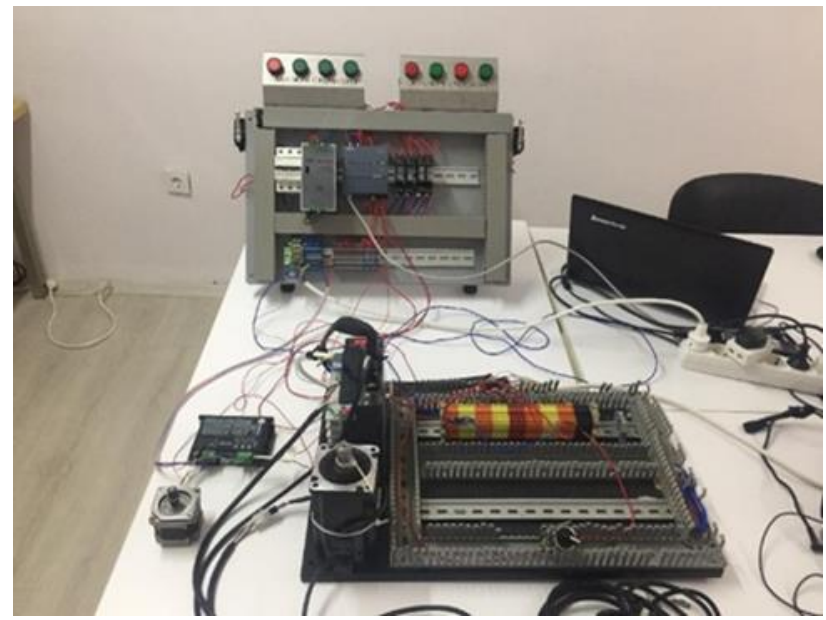

Figure 4. S7-1200 PLC connected system

Step and servo motor control function is created and prepared.

The sequence of action for the project is as follows:

1- The program is opened and the PLC device is added.

2- Technology objects are opened and the "add new block" is clicked. To_Axis_PTO is selected from the opened motion control tab. Axis adjustment is done for both step motor and servo motor. Accordingly, Axis 1 (step motor) and Axis2 (servo motor) are created. The creation structure of Axis 1 and Axis 2 axes are the same.

\section{Product Control with S7-1500 PLC}

In the application to be made with the S7-1500, the products passing over the conveyor are read with two different sensors. According to the reading values, depending on the algorithm on the PLC, it is decided whether the product is defective or not. Defective products are separated by pushing them over the conveyor with a pneumatic valve. Figure 5 shows the system set up in a laboratory environment; 


\begin{tabular}{|c|c|c|}
\hline & $\begin{array}{l}\text { BŞEÜ Fen Bilimleri Dergisi } \\
8(1), 336-344,2020\end{array}$ & $\begin{array}{r}\text { BSEU Journal of Science } \\
\text { https://doi.org/10.35193/bseufbd.899424 }\end{array}$ \\
\hline 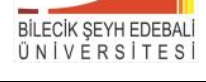 & & 2458-7575 (https://dergipark.org.tr/tr/pub/bseufbd) \\
\hline
\end{tabular}

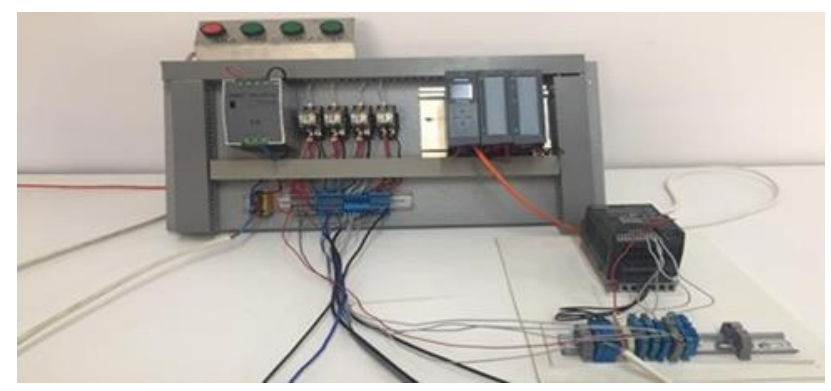

Figure 5. Siemens Sinamix V20 asynchronous motor drive with S7-1500 PLC connected in laboratory environment

After the connection is made, a Ladder diagram is created using TIA Portal software, and product control is implemented. Ladder diagrams of S7-1500 PLC system installed in TIA Portal environment are written using 7 networks.

\section{Reading Humidity and Temperature Information with Arduino and Sending It to SCADA by Serial Communication}

In the application to be made with Arduino, the temperature and humidity of the greenhouse to which the system is connected is controlled. The values read from the temperature and humidity sensor are sent to the SCADA system via serial communication over the master device. Figure 6 shows the connection diagram of the system to be built with Arduino;

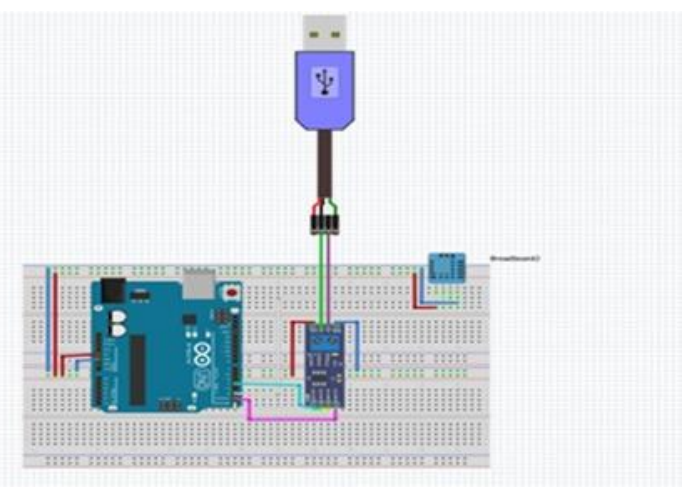

Figure 6. Connection diagram of Arduino and DHT11 temperature and humidity sensor

In the Automation Academy R\&D laboratory environment, the shape of the system with a connection diagram is shown.

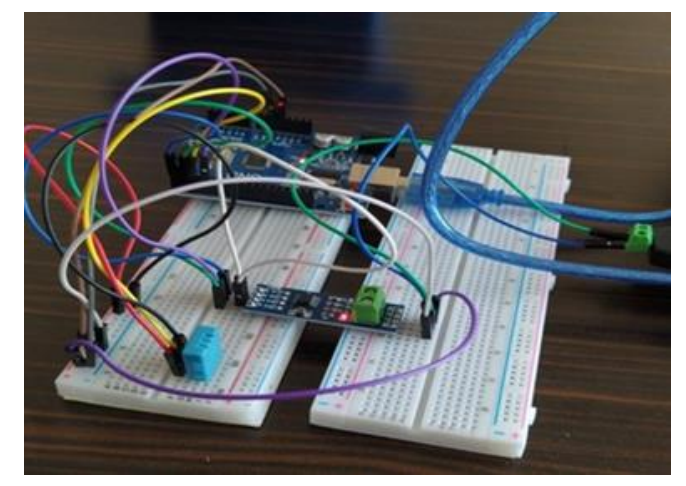

Figure 7. Connection of DHT11 humidity and temperature sensor with the connected Arduino

The program is written in Arduino IDE using Modbus Rtu and DHT11 libraries. 


\begin{tabular}{|c|c|c|}
\hline & $\begin{array}{l}\text { BŞEÜ Fen Bilimleri Dergisi } \\
8(1), 336-344,2020\end{array}$ & $\begin{array}{r}\text { BSEU Journal of Science } \\
\text { https://doi.org/10.35193/bseufbd.899424 }\end{array}$ \\
\hline 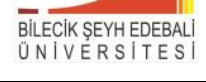 & & 2458-7575 (https://dergipark.org.tr/tr/pub/bseufbd) \\
\hline
\end{tabular}

\section{ESTABLISHING SCADA SYSTEM OF DEVELOPED APPLICATIONS}

S7-300, S7-1200 and S7-1500 PLC types are made under a single project in TIA Portal software. The WINCC SCADA project is also added to this project. For adding the WINCC SCADA project, the procedures are performed as described in chapter 3 . The connection of the added SCADA system with PLC types is implemented using PROFINET. By clicking the Device \& Networks tab, the connection scheme of the devices communicating with each other is seen. The following figure shows the connection of PLC devices (S7-300, S7-1200 and S71500) and Modbus device communicating with the SCADA system:

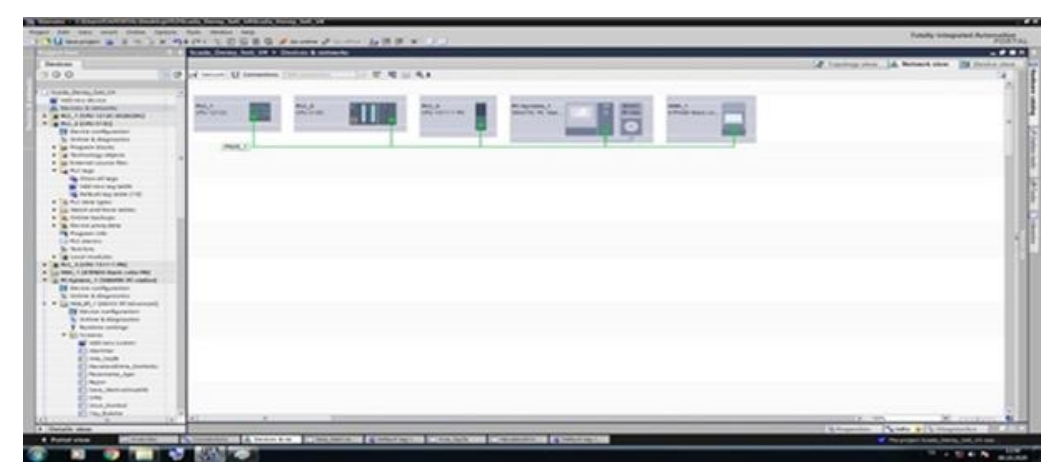

Figure 8. Connection of SCADA system and PLC and Modbus devices

Connection types that the systems to be controlled communicate with SCADA are configured in the connection menu. The list of devices added to the SCADA system is displayed in this menu. In this study, Modbus and 3 PLC devices are used with together. The interface that enables these devices to connect with the computer, that is called the modem, is selected respectively. following:

7 pages are created in accordance with the practices developed in this study. The created screens are the

1- Main page

2- Ventilation Control

3- Spring Bending

4- Product Control

5- Greenhouse Humidity and Temperature

6- Alarms

7- Parameter Setting

8- Report

9- Password

There are general information on the main screen. All of them are added to the home screen to allow easy access to other screens. The product control page of this work is shown in Figure 9;

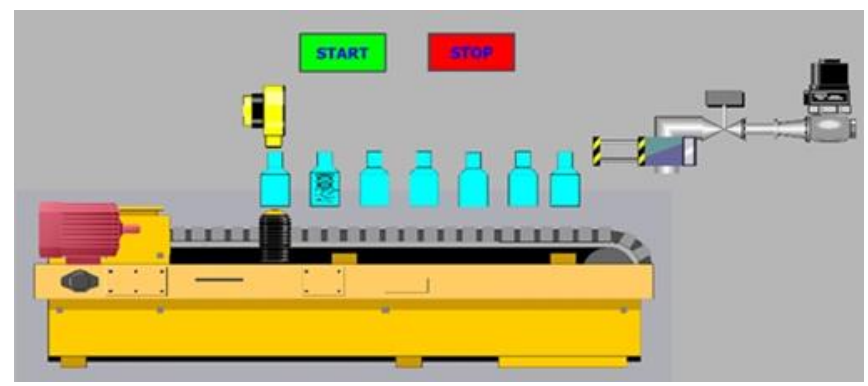

Figure 9. Product control 
After all pages are created and tasks are assigned to the buttons, the installed SCADA project becomes operational. It is possible to view four applications from one screen.

\section{CONCLUSION}

In this work, the developed applications are; temperature dependent speed control, synchronous operation of step and servo motors of spring bending machine, product control, reading humidity and temperature information with Arduino and sending it to SCADA by serial communication. First three systems are connected to SCADA using different types of PLC, S7-300, S7-1200, S7-1500 respectively and also MODBUS devices. These four systems transferred to SCADA are monitored on a screen. At the same time, one of the significant advantages of the SCADA system is that it permits to intervene in the system in the case of malfunction. As a result of the study, it is made possible to monitor all applications connected to the SCADA system from a single screen, and the data received from all receivers are monitored on the SCADA screen and also reported. It is made possible to detect the malfunctions immediately without losing time and to delete them from the remote-control system. As a result of the study, the importance of the SCADA system installed in automation technology in terms of both time and convenience is revealed once again.

\section{ACKNOWLEDGMENT}

This study has been implemented in the Academy Automation R\&D Laboratory.

\section{REFERENCES}

[1] Selek, A. (2020). What is PLC?, https://www.endustri40.com/tia-portal-nedir, (Visit date: 20 September 2020).

[2] Sechen, H. İ. (2014). The future of PLC, https://www.elektrikport.com/teknik-kutuphane/siemens-plcteknolojileri/12311\#ad-image-0, (Visit date: 15 September 2020).

[3] Brodzik, R. (2014). History of PLC, https://www.controleng.com/articles/inside-the-competition-for-thefirst-plc/, (Visit date: 18 September 2020).

[4] Thomas, M.S., Kumar, P. \& Chandna, V.K. (2004). Design, development, and commissioning of a supervisory control and data acquisition (SCADA) laboratory for researc hand training, IEEE transactions on Power System, 19, 3, 1582- 1588.

[5] Eminoglu, Y. (2016). PLC Programming and S7 300/400, Birsen Publication, Istanbul, ISBN: 978-975-511550-4.

[6] Demir, D., Tepe, C. \& Eminoğlu, İ. (2019). Experimental setup for AC motor speed control by using PLC, Journal of Scientific Perspectives, 3(3), 177-188. DOI: 10.26900/jsp.3.018.

[7] Gajbhiye, Y.Y., Pjagtap, P. \& Helonde, J.B. (2014). Labviewstudy of electrical power distribution system by using Simatic S7-300 PLC system, IJRET: International Journal of Research in Engineering and Technology, 3(4), 143-150.

[8] Demirci, A. (2012). SCADA implementation on PLC based experimental sets in the laboratorysetting, M.Sc., Marmara University, Institute of Science.

[9] Kaur, K. \& Kaur, R. (2014). Energy management system using PLC and SCADA, International Journal of Engineering Research \& Technology (IJERT), 3(11), 528-531.

[10] Eminoglu, Y. (2017). PLC Programming and S7 1200, Programming and S7 300/400, Birsen Publication, Istanbul, ISBN: 978-975-511-588-7.

[11] Kayri, İ. (2003). Controlling the temperature value of medium by using programmable logic controller, M.Sc., Yuzuncu Yil University, Institute of Science.

[12] Irmak, E., Erkek, İ. \& Özçelik, M. (2017). Experimental analysis of the internal attacks on SCADA systems, Gazi University Journal of Science, 30(4), 216-230.

[13] Eminoğlu, Y. (2016). Operator Panel with TIA portal \& SCADA programmin, Birsen Publication, İstanbul, ISBN: 978-975-511-649-5.

[14] Lishev, S., Popov, R. \& Georgiev, A. (2015). Laboratuvar SCADA sistemleri - Son teknoloji ve zorluklar, Balkan Elektrik ve Bilgisayar Mühendisliği Dergisi, 3(3), 164-170.

[15] Şimşek, M. \& Özen, M, F. (2019). "Realization of a building automation system using PLC and SCADA", International Journal of Engineering and Innovative Research, 1(1), 28-34.

[16] Dorjee, R. G. (2014). Monitoring and control of a variable frequency drive using PLC and SCADA, International Journal on Recent and Innovation Trends in Computing and Communication, 2(10), 3092-3098 


\begin{tabular}{|c|c|c|}
\hline & $\begin{array}{l}\text { BŞEÜ Fen Bilimleri Dergisi } \\
8(1), 336-344,2020\end{array}$ & $\begin{array}{r}\text { BSEU Journal of Science } \\
\text { https://doi.org/10.35193/bseufbd.899424 }\end{array}$ \\
\hline$V E R$ & & :2458-7575 (https://dergipark.org.tr/tr/pub/bseufbd) \\
\hline
\end{tabular}

[17] Üstünsoy, F. \& Sayan, H. H. (2018). PLC destekli SCADA ile enerji yönetimi için örnek laboratuvar çalışmasi, Politeknik Dergisi, 21(4), 1007-1014. 